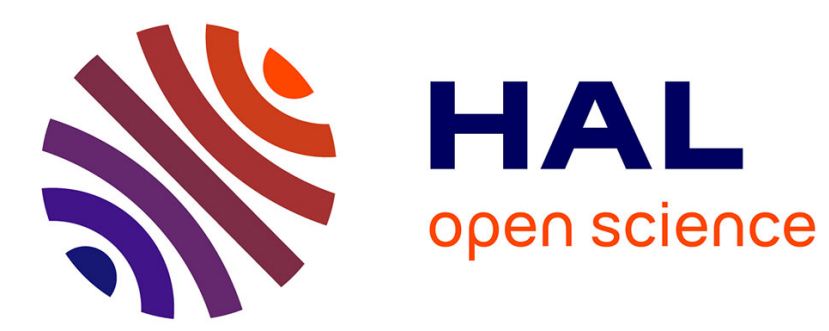

\title{
COAL CLEANING BY HIGH GRADIENT MAGNETIC SEPARATION
}

\author{
C. van Driel, J. Sikkenga, C. Kerkdijk
}

\section{To cite this version:}

C. van Driel, J. Sikkenga, C. Kerkdijk. COAL CLEANING BY HIGH GRADIENT MAGNETIC SEPARATION. Journal de Physique Colloques, 1984, 45 (C1), pp.C1-775-C1-778. 10.1051/jphyscol:19841158 . jpa-00223631

\section{HAL Id: jpa-00223631 https://hal.science/jpa-00223631}

Submitted on 1 Jan 1984

HAL is a multi-disciplinary open access archive for the deposit and dissemination of scientific research documents, whether they are published or not. The documents may come from teaching and research institutions in France or abroad, or from public or private research centers.
L'archive ouverte pluridisciplinaire HAL, est destinée au dépôt et à la diffusion de documents scientifiques de niveau recherche, publiés ou non, émanant des établissements d'enseignement et de recherche français ou étrangers, des laboratoires publics ou privés. 


\author{
C.P. van Drie1, J. Sikkenga* and C.B.W. Kerkdijk \\ FDO Engineering Consultants, P.O. Box 379, $1000 \mathrm{AJ}$ Amsterdam, The Netherlands \\ ${ }^{*}$ Holec Nederland B.V., P.O. Box 23, 7550 AA Hengelo, The Netheriands
}

\begin{abstract}
Résumé - Les résultats d'expériences de purification de charbon en HGMS sont présentés. L'accent est mis sur la relation entre les rêsultats de la purification et les caractéristiques du charbon.

Abstract - Results of experimental work on HGMS coal cleaning will be presented with emphasis on the relation between cleaning results and coal characteristics.
\end{abstract}

\title{
I INTRODUCTION
}

High Gradient Magnetic Separation (HGMS) is a particle separation technique which is based on the differences in the magnetic properties of the particles. A survey of the principles, theory, experimental work and applications has been given by Birrs and Parker /1/.

HGMS can be applied to pulverized coal in order to remove pyritic sulphur and ash forming minerals, thus producing a clean coal. Pyrite and mineral matter particles are removed by strong magnetic forces due to these particles being paramagnetic. For practical purposes, pure coal particles can be considered to be non-magnetic and are therefore not affected by strong magnetic field gradients.

Fly ash can be processed by HGMS to obtain two or more fractions which differ in properties, among others color, particle size, and chemical composition (mainIy of Fe and trace elements). The separation is accomplished due to the presence or absence of highly paramagnetic iron compound in the individual fly ash particles.

Extensive HGMS coal cleaning experiments on four German coal types have been performed and are reported by Van Driel et al. /2,3/. Also four fly ashes, originating from coal fired electric utility boilers, were used in experimental work on HGMS fly ash upgrading. Experimental results are reported by Van Driel et al. $/ 4 /$.

In this paper some results of the HGMS coal cleaning experiments will be presented, more specific, the dependence of coal cleaning results on the coal characteristics will be treated. For more detailed results the reader is referxed to Ref. 2 .

II COAL CLEANING BY HGMS

Coal can be considered as a mixture of pure coal and mineral matter (mm). Pure coal can be considered to be non-magnetic for práctical purposes (in fact it is diamagnetic), while the $\mathrm{mm}$ is either non-magnetic or paramagnetic.

In the ideal case, coal cleaning by HGMS proceeds as follows: coal is pulverized as to produce a mixture of pure coal and pure $\mathrm{mm}$ particles. This mixture is supplied to an HGMS-system. The paramagnetic particles are removed from the mixture by strong magnetic forces (which should exceed the other forces on the 
particles, viz. viscous, gravity and inertial forces), while the non-magnetic particles are unaffected by the magnetic field strength gradients. Therefore, in the ideal case, coal is produced with less $\mathrm{mm}$ (the non-magnetic minerals end up with the non-magnetic coal). Sulphur bound in pyrite (FeS2) is removed; pyrite is paramagnetic.

In practice, pulverization of coal will also lead to the presence of mixed particles, i.e. particle containing both coal and mineral matter. These mixed particles result in an incomplete separation of paramagnetic mm from pure coal particles: the cleaned coal contains more $\mathrm{mm}$ than in the ideal case. Also coal is removed by magnetic forces if a paramagnetic $\mathrm{mm}$ particle adheres to a coal particle: coal is lost in the refuse stxeam.

Van Driel et al. /2,3/ reported on the removal of pyritic sulphur and ash forming minerals from four German coal types (labelled \#\#3,4(III), 7(III), and Pattberg) using HGMS. Pulverized coal samples (pulverized to 100\% - 200 mesh) were treated in the form of a $30 \%$ wt coal-water slurry at magnetic field strengths of up to 7 Tesla at slurry transport velocities up to $25 \mathrm{~cm} / \mathrm{s}$. Grade-recovery curves at different process conditions were obtained.

Maximum pyritic sulphur reductions ranging from 40 to $95 \%$, and ash reductions ranging from 60 to $75 \%$ were obtained at high magnetic field strengths ( 7 Tesla) and low slurry velocities $(1.5 \mathrm{~cm} / \mathrm{s})$. Detailed results are given in Table 1 .

Table 1 Best results with wet HGMS

\begin{tabular}{|c|c|c|c|c|c|c|c|}
\hline \multirow{2}{*}{ Coal } & \multicolumn{2}{|l|}{ ash } & \multicolumn{2}{|c|}{ TS } & \multicolumn{2}{|c|}{$\overline{\mathrm{PS}}$} & \multirow{2}{*}{$\begin{array}{c}\text { recovery } \\
\text { \& }\end{array}$} \\
\hline & $\begin{array}{c}\text { prior to } \\
\text { cleaning } \\
8\end{array}$ & $\begin{array}{l}\text { ash. } \\
\text { red. } \\
\text { \& }\end{array}$ & $\begin{array}{l}\text { prior to } \\
\text { cleaning } \\
\end{array}$ & $\begin{array}{l}\text { TSS } \\
\text { red. }\end{array}$ & $\begin{array}{l}\text { priox to } \\
\text { cleaning } \\
\$\end{array}$ & $\begin{array}{l}\text { PS } \\
\text { red. } \\
\$\end{array}$ & \\
\hline 3 & 3.8 & 74 & 0.91 & 21 & 0.27 & 52 & 91 \\
\hline 4 (III) & 10.5 & 69 & 1.05 & 18 & 0.34 & 38 & 80 \\
\hline 7 (III) & 4.8 & 75 & 1.10 & 40 & 0.38 & 96 & 71 \\
\hline Pattberg & 7.1 & 59 & 1.12 & 26 & 0.32 & 75 & 87 \\
\hline
\end{tabular}

\author{
Conditions: $v=1.7 \mathrm{~cm} / \mathrm{s}$ and $\mathrm{B}=7 \mathrm{~T}$. \\ (percentages are on a daf basis)
}

Recovery (i.e. Btu-recovery, or the percentage of heating value of the feed which is collected in the cleaned fraction) ranged from 70 'to $90 \%$. It should be emphasized that the processconditions at which the best results are obtained are not necessarily processconditions from an economic point of view.

The mineral matter composition has been determined, see Table 2 .

Table 2 Mineral matter composition (\% by weight)

\begin{tabular}{|c|c|c|c|c|}
\hline $\overrightarrow{M i}$ & 3 & 4 (III) & $7($ III $)$ & Pattberg \\
\hline quartz & - & - & - & 5.9 \\
\hline illite & 3.7 & 6.8 & - & 25.7 \\
\hline pyrite & 11.9 & 6.8 & 20.7 & 22.2 \\
\hline siderite $\left(\mathrm{FeCO}_{3}\right)$ & 53.7 & 61.6 & 18.2 & 9.6 \\
\hline calcite $\left(\mathrm{CaCO}_{3}\right)$ & 11.1 & 6.3 & 43.6 & 6.8 \\
\hline ankerite & 7.3 & 10.6 & - & 5.8 \\
\hline Fe-sulphate & 4.2 & - & 5.2 & - \\
\hline kaolinite & 3.2 & 2.5 & 6.0 & 8.7 \\
\hline mixed silicates & - & 2.1 & - & 8.6 \\
\hline mixed sulphates & - & - & 1.9 & - \\
\hline misc. +unknown & 4.9 & 3.2 & 4.3 & 6.7 \\
\hline total & 100 & 100 & 100 & 100 \\
\hline
\end{tabular}


From this mm composition, the ash reduction has been calculated assuming that HGMS only removes paramagnetic mm particles (recovery data are also included in the calculation, therefore the calculated ash reduction can be negative). Experimentally obtained ash reductions are larger, see Table 3 for a comparison.

Table 3 Comparison between calculated and measured ash reduction

\begin{tabular}{|l|c|c|}
\hline $\begin{array}{l}\text { Coal } \\
\#\end{array}$ & $\begin{array}{c}\text { calculated } \\
\text { ash reduction } \\
8\end{array}$ & $\begin{array}{l}\text { measured } \\
\text { ash reduction }\end{array}$ \\
\hline 3 & 44 & 8 \\
$4($ III $)$ & 7 & 74 \\
$7($ III) & -6 & 69 \\
Pattberg & -8 & 75 \\
\hline
\end{tabular}

Therefore it is concluded that non-magnetic $\mathrm{mm}$ is removed by HGMS. This can be explained by the presence of conglomerates of non-magnetic and paramagnetic minerals.

The magnetic susceptibility of the coal samples has been obtained, and using the mineral matter composition data, the magnetic susceptibility of the natural

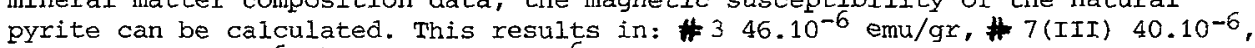

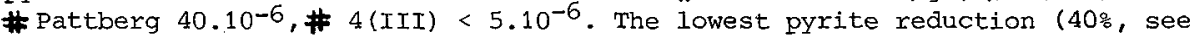
Table 1) has been obtained for coal \#4(III) which shows some consistency with the magnetic susceptibility data. It should be emphasized however that nevertheless $40 \%$ pyritic sulphur has been removed.

The HGMS theory on particle capture efficiency, which has been shown to be valid in a large number of single and multiple wire capture experiments, indicates that a nearly $100 \%$ capture efficiency can be expected for micronsize pyrite particles, even at low magnetic susceptibilities (say 1 to $5.10^{-6} \mathrm{emu} / \mathrm{gr}$ ). This $100 \%$ pyxite removal is essentially obtained for \# (III); pyrite particle size equals $17 \%$ wt $<5 \mu \mathrm{m}, 39 \%<10 \mu \mathrm{m}$, and $53 \%<20 \mu \mathrm{m}$. For \# 3 and Pattberg, which has a comparable pyrite particle size as \#7(III), an incomplete pyrite removal is obtained. This should be attributed to an incomplete liberation of pyrite from the coal matrix. No quantitative information on the degree of liberation was obtained in the present work.

In this paper emphasis was on the relation between pyritic sulphur and $\mathrm{mm}$ reduction and coal characteristics. If such a relation can be established and quantified, HGMS coal cleaning performance can be predicted. This predictability is of utmost importance in a situation where an HGMS system is meant to process different and varying types of coal.

For the PETC two-stage coal-pyxite flotation process an excellent correlation between expeximentally obtained and predicted pyritic sulphur reduction has been obtained /5/. The prediction is based on the following coal characteristics: reflectance rank, fraction of liberated pyrite, pyritic sulphur as a percentage of total sulphur, percent of pyrite with size smaller than 32 m. A similar approach should be followed for the HGMS process in order to establish and quantify the cleaning versus coal characteristics relationship.

\section{ACKNOWLEDGEMENTS}

The authors wish to thank: the staff of the High Field Magnet Laboratory of the Catholic University of Nijmegen for support during the experimental work, Dr. J. Vleeskens of the Energy Research Foundation in Petten for providing the mineral matter composition data. 


\section{REFERENCES}

1. Birrs R.R. and Parker M.R., High Intensity Magnetic Separation, published in Progress in Filtration and Separation Volume 2, Ed. Wakeman R.J., Elsevier 1981 .

2. Van Driel C.P., Kerkdijk C.B.W., Segal H.R., and Sikkenga J., Coal Cleaning by HGMS, February 1983(Available from FDO, P.O. Box 379, Amsterdam, the Netherlands).

3. Van Driel C.P., Kerkdijk C.B.W., Segal H.R., and Sikkenga J., Coal Cleaning by HGMS, August 1983 (Available from EDO, P.O. Box 379, Amsterdam, the Netherlands).

4. Van Driel C.P., Kerkdijk C.B.W., and Sikkenga J., FlY Ash and AFBC Ash Upgrading by HGMS, August 1983, To be published.

5. Tomich R.S., Petrographic evaluation in the products from two-stage coal-pyrite flotation; DOE/PC-30134-1, November 1981. 